\title{
児童期における自己評価と親子相互作用 「意見尊重的態度」に関する分析から
}

The relationship of self-esteem and parent-child interaction in middle childhood: An analysis of attitudes on mutual respect

\author{
眞榮城 和美 藤森 秀子 \\ 白百合女子大学 \\ 大学院文学研究科 \\ 横浜市立脳血管
}

\author{
八木下 暁子 \\ 東京都立大学大学院
}

菅原 ますみ
国立精神・神経センター

北村 俊則

\section{問 題}

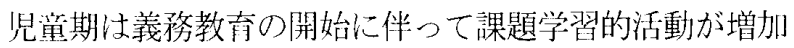
することにより，他者からの評価を受ける機会も增寸時期 である。その中で，子どもたちは自己に対するまなざしを 変化させていくものと考光られている（梶山，1988）。 た, 他者の有能さについての客観的な評価に伴い, 劣等感 が高まりやすく, 自己評価が低下寸る傾问の強い時期であ る（Erikson, 1950）ことから，児童期における自己評価 の発達に関連する要因に注时ることは，子どもが著しく 自己評価を低下させることなく, 社会に対する自己の主体 性を形成していく手がかりを得る上で重要な視点であると 考えられる。

児童期に抢ける自己評価の発達に重要なかかわりを持つ 要因迤数多く存在するが, 特に, 親の養育態度との関連性 は注目され続けているものであり，母親の受容的，自律性

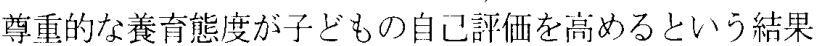
が示されている（㷊下，1988）。また，男子は母親に受容 されていると認識できることが，女子は母親から自律性を 尊重されていると認識できることが自己評価を高める (Kawash, Keer \& Clewes, 1985)，といら報告があるよ らに，母子関倸と子どもの自己評価の関連に执いては性差 があることも認少られている。しかしながら，父子関係と 子どもの自己評価の発達との関連を検討したものは少なく， 性差の検討老行うためには，父子関係にも焦点を当て，親 子性别組み合わせによる違い在検討寸る必要があるものと 考えられる. また, 親の養育態度のみに焦点を当てるので はなく，子どもの主体的な態度を検討するためにも，質問 紙法による調查研究に加え，上り実際的な親子の相互作用 に注目寸ることが求められているものと思われる。 そこで 本研究においては, VTRを用いた行動観察を行い，子ど もの自己評価と関連が認められる親子相互作用について検 討することとし，特に，実際の討論場面において，子ども と親の双方に見られる受容的・自律尊重的態度の指標とし て「相手の意見を尊重寸る態度」に焦点を当て, 親子性別 組み合わせによる違いに注目した検討を試みた。

\section{方 法}

\section{調查対象者および手続き}

1984 年 8 月に神奈川県 $\mathrm{K}$ 市市立病院産婦人科で詨象児 を出産した家族について開始された紂断的研究（Kitamura， Sugawara, Sugawara, Toda \& Shima, 1996; 菅原・北 村・戸四・島・佐藤・向井, 1999）に登録されている被験
者の5ち, 出産後 11 年目の追跡調查に灾じた 313 家族（母 親 386 名, 父親 325 名, 子ども 400 名）在刘象とした。 な お，本研究における質問紙分析対象児は 384 名（男子 188 名，女子 196 名），平均年齢仗 10.52 歳（9歳〜11歳）で あり，著しい発達の遅れや，発達障害等涊衿られなか。 た。質問紙は郵送によって配布・回収（刘象615家族， 回収率 $62.6 \%)$ され，調查期間は，1996 年 7 月〜 1997 年 8 月であった。

質問紙調查に问答した 313 家族の中で，直接行動観察に 态じた 66 家族に対し，行動観察課題を行った。2 家族に ついては，時間の制約から親子相互作用の観祭が完「でき なかったため, 調查刘象から除外し, 男児 35 名, 女児 29 名（平均年齢 10.19 歳）とその雨親（父親の平均年齢 41.68 歳，母親の平均年齢 38.54 歳）の計 64 家族を分析の刘象 とした. 行動観察調查期間は 1996 年: 8 月〜 1997 年 4 月で あった。

\section{子どもの自己評価の測定}

巟童期に扮ける自己評伍を測定する代非的な尺度の1つ であるSelf-Perception Profile For Children (Harter， 1985）を翻訳して用いた。原尺度は6 領域 36 項目から構 成されているが，今回の研究では各領域から 3 項目ずつ計 18 項目を使用した。この尺度は「運動能力」・学業能力」 「容姿」「「友人関係」「品行」「「全体的自己価值感（自己 受容感)」(「スポーツならなんでもよくできる」・学校の 勉強がとてもよくできる」・自分の身長と体重に市んぞく している」・「たくさんの友達がいる」・「とても拉ぎょうぎ がよい」・「自分のような人が好きだ」他 12 項目）を測定 する項目から成り立っている。評定方法は「はい」「少し はい」「少しいいえ」「いいえ」の4段階であった。

本研究に执いては, 各側面別自己評洒ではなく, 上り大 きな意味での自己評価の検討を目的としていることから， 解析には 18 項目の総合得点を用いることとした. Harter

(1985)の先行研究加 $， 6$ 領域間の内部相関は.28〜.67 であり，おおむ枚中程度以上の関連性があることが確認さ れている. 本研究のサンプルについて, 各領域の相関関係 を確認したところ，どの領域执いても「全体的自己価值 感 (自己受容感)」との相関関係が $.22 \sim .75$ の間で認めら れた. また, これら 18 項目の信頼性を算出したところ, $\alpha=.80$ という值が得られ，一次元性を確認することがで きたので, 18 項目を加算した得点を総合的な自己評価指 標として分析に使用した。

\section{親子相互作用の観察}

家族の日常場面にできるだけ近い実験状況を設定するた 
めに, 都内の家具付き $3 \mathrm{LDK}$ マンションを観察施設とし て家族相互作用の直接観察在実施した。 また，両者の表情 を捉えるために，デジタルビデオカメラ 2 台（サイド及び フロント）を設置し，VTR 録画を行った。課題は Social Support Interaction Cording System (Bradbury \& Pasch, 1994）に基づき，親子の一方による個人的な悩み 事の開示 (当該 2 者間の関係に関寸る悩み俆く) に対し てもら一方がアドバイス寸るという討論場面を設定した（課 題遂行時間双各 5 分間)。本研究に㧈いては録画された以 下の 4 場面を分析の対象とした。 1. 子どもが母親に対し て恼み事を相談する場面（子十母の自己開示場面）。2.

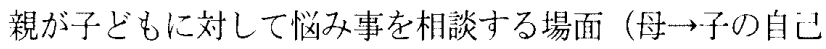
開示場面). 3. 子どもが父親に対して恼み事を相談する場 面（子小父の自己開示場面）。4.父親が子どもに対して恼 み事を相談する場面（父子子の自己開示場面）。

\section{分析手続き}

VTR 在再生し，前述の 4 場面に詨する評定を行った。 今回の分析では親子相互に見られる相手の意見を尊重する 態度（「意見尊重的態度」）に焦点老当て，「意見在尊重し ている」〜「意見を尊重していない」までの 5 段階で評 定老行った。なお，本研究で焦点を当てた「意見尊重的態 度」と注，具体的には「そうだ称「てら思う」「そうしよ うかな」などの相手の意見に同意を示守富語的反态，及び， 相手の意見に対して「領く」などの相于の意見を尊重する 非言語的反忘を対象とした。

評定は 5 名の評定者（女性）がランダムに 2 名一組とな り実施した，評定者間の- 致度（評定者間相関）は $r=.70$ 〜.87であった。 各場面についての親子相互の「意見尊重 的態度」の評定値を以降の分析に用いた。

\section{結果}

結果はすべて SPSS 統計パッケージを用いて分析された。 子どもの総合的自己評価と親子相互の意見尊重的態度との関連

1）場面 1 (子小母の自己開示場面）で汒, 男子の総合的 自己評価と「子 $\Rightarrow$ 母の意見尊重的態度」との間に中程 度の正の相関が認められた (Table 1 参照)。

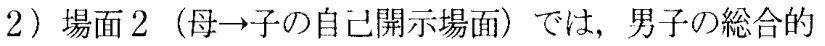
自己評価と「母 $\Rightarrow$ 子の意見尊重的態度」「子 $\Rightarrow$ 母の意 見尊重的態度」との閒に中程度の正の相関が認められ た (Table 2 参照).

3）場面 3 (子 $\rightarrow$ 父の自己開示場面)，場面 4(父 $\rightarrow$ 子の

Table 1 子小親の自己開示場面における子どもの総合的自し評価 之親 $\Leftrightarrow$ 子の意見尊重的態度との関連

\begin{tabular}{|c|c|c|c|c|c|c|}
\hline & & & \multicolumn{4}{|c|}{ 意自尊重的態度 } \\
\hline & & & 母 $\Rightarrow$ 子 & 子 $\Rightarrow$ 舴 & 父 $\Rightarrow$ 子 & 子 $\Rightarrow$ 父 \\
\hline 総合 的 & 男 & 子 $(n=35)$ & .21 & $.42^{* *}$ & .15 & .07 \\
\hline 目主評価 & 女 & 子. $(n=29)$ & -.27 & .19 & -.07 & .04 \\
\hline
\end{tabular}

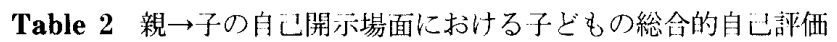
と親 $\Leftrightarrow 子 の$ 意見尊重的態度との関連

\begin{tabular}{|c|c|c|c|c|c|c|}
\hline & & & \multicolumn{4}{|c|}{ 意見㩊重的態度 } \\
\hline & & & 过 $\Rightarrow$ 子 & 子 $\Rightarrow$ 辰 & 父 $\Rightarrow$ 子 & 子 $\Rightarrow$ 父 \\
\hline 総合 的 & 责 & 子 $(n=35)$ & $.42^{*}$ & $.45^{*}$ & .21 & .11 \\
\hline 自乞評価 & 女 & 子 $(n=29)$ & -.32 & .26 & -.26 & -.02 \\
\hline
\end{tabular}

自己開示場面）では，男女ともに総合的自己評価と親 子相互の意見尊重的態度との間に関連が認められなかっ た (Table 1, 2 参照).

\section{考察}

児童期に㧍ける自己評価と親子相互の意見尊重的態度と の関連に焦点老当てた分析の結果, 岁子の自己評価の高さ 上関連の得られた母子相互作用は，「扔互いの意見を尊重 し合えること」であった。つまり，母親が子どもの意見を 尊重する態度を示すことが男子の自己評価を高衣作用を 持つと同時に，自己評価の高い男子は母親の意見を尊重す ることができるといら，子どもの態度に主体性が認められ たものと考えられる。..方，女子の自己評価の高さと母子 相互作用との関連は認められなかった。この結果は, 先行 研究（Kawash et al., 1985）にて報告されているように, 母子相互作用と子どもの自己評価との関連に沶汁る性差を 示唆するものと言えよう。このような性差が生じた背景に は様々な要因が存在するが，その1つとして，母－息子 関係，母一娘関係に㧍ける質的な違いを挙げることがで きるのではなかららか，さらに本研究においては，母子相 互作用のみならず, 子どもの自己評価と父子相互作用との 関連を検討した。しかしながら，男女ともに関連淿られ なかった。これ让，男子の自記評価を高奻万親子相互作用 として, 父子相互作用以上に母子相互作:用の重要性が示さ れた結果であると捉えることができよう。但し，今回の分 析は親子相互に見られる意見尊重的態度のみに焦点在当て たものであるため, 今後は，さらに詳細な親子の対話分析 を行い，多様な非言語的相互作用にも注月寸ることにより， 子どもの自己評価を高める親子相互作用について検討して いく必要性があるものと考えている。

\section{引用文献}

Bradbely, TN., \& Parsch L. A. 1994 Social support interaction coding system. Unpublished coding manual, University of California, Los Angeles.

Erikson, E. H. 1950 Childhood and society. New York: W. W. Norton.

Harter, S. 1985 Self perception profile for children. University of Denver, co

梶田㪍一 1988 自己意識の心理学 東京大学出版会

Kawash, G. F, Keer, E. N., \& Clewes, J. L. 1985 Selfesteem in children as a function of perceived parental behavior. Journal of Psychology, 119, 235-242.

Kitamura, T., Sugawara, M., Sugawara, K., Toda, M., \& Shima, S. 1996 A psychosocial study of depression in early pregnancy. British Journal of Psychiatry, 168, 732-738.

森下正康 1988 児童期の母子関係とパーソナリティの発達 心理学研究, 31 (1), $60-75$.

菅原ますみ・北村俊則・F田まり・島 悟・佐藤達哉・向井隆 代 1999 子どもの問題行動の発達 : Externalizing な問題 傾向に関する生後 11 年間の䋛断的研究から 発達心理学研 究, $10(1), 32-45$.

- 2000.7.24. 受稿, 2001. 7.6. 受理- 